$\underline{\text { Review Article }}$

\title{
ANALYTICAL METHODS FOR THE DETERMINATION OF HYDROXYCHLOROQUINE IN VARIOUS MATRICES
}

\section{ALANKAR SHRIVASTAVA}

Department of Pharmaceutical Quality Assurance, KIET School of Pharmacy, KIET Group of Institutions, Ghaziabad

Email: alankar.shrivastava@kiet.edu

Received: 26 May 2020, Revised and Accepted: 20 Jun 2020

\begin{abstract}
Hydroxychloroquine (HCQ) is classified under the class of drugs called antimalarials. This is used for preventions and treatment of malaria. HCQ is also used in the treatment of DLE (Discoid Lupus Erythematosus) or SLE (Systemic Lupus Erythematosus) and RA (Rheumatoid Arthritis). Recently, this drug attracts its attention by scientists of all of the worlds for its potential activity in the improvement of conditions of covid patients. There are many clinical trials are under process to prove its activity against this dangerous virus. The presented review describes different analytical procedures for the analysis of HCQ in various components available in the currently available literature. The paper will be certainly helpful for the scientists and researchers engaged in research, especially in the development of formulation or quality assurance of HCQ. The results of any clinical trial also includes the determination of drug in body fluids for interpretation of data. The analytical methods described here are explained in three parts; spectrophotometry, chromatography and other (including capillary electrophoresis and electroanalytical methods)
\end{abstract}

Keywords: Hydroxychloroquine, Spectrophotometry, Chromatography methods, Electroanalytical methods, Methods for determination of Hydroxychloroquine, Determination of hydroxychloroquine

(C) 2020 The Authors. Published by Innovare Academic Sciences Pvt Ltd. This is an open access article under the CC BY license (http://creativecommons.org/licenses/by/4.0/) DOI: http://dx.doi.org/10.22159/ijap.2020v12i4.38408. Journal homepage: https://innovareacademics.in/journals/index.php/ijap

\section{INTRODUCTION}

Hydroxychloroquine (HCQ) is more commonly used than chloroquine, is a well-tolerated Disease-modifying anti-rheumatic drugs (DMARD) that is commonly used in combination therapy regimens for RA [1]. The IUPAC name of HCQ $\left(\mathrm{C}_{18} \mathrm{H}_{26} \mathrm{ClN}_{3} \mathrm{O}\right)$ is $(R S)$ 2-[4-(7-Chloro-4-quinolylamino)pentyl(ethyl)amino]-ethanol [2].

The HCQ is synthesized by an antimalarial drug, chloroquine (CQ) with incorporating hydroxyl group in its structure, in the year 1946. After the discovery of HCQ it was found to be two to three times less toxic than CQ [3]
Hydroxychloroquine (fig. 1) is a 4-aminoquinoline shown to possess the above-described activities. This is also known to be an immunosuppressant drug. The abnormalities caused by HCQ therapy is rare compared with CQ, which is also associated with acute liver lesion [4]. HCQ is available in the market in the form of tablet formulations. The dose of HCQ ranges from $100 \mathrm{mg}$ to 1.2 grams per day, quickly absorbed in two to four hours. The absorbed portion is about $74 \% \pm 13 \%$. The blood concentration of HCQ rises shortly after absorption but fall rapidly due to fast distribution into organs of the body [5]<smiles>CCN(CC)CCCC(C)Nc1ccnc2cc(Cl)ccc12</smiles>

(1)

$\mathrm{HCQ}$

$\mathrm{DCQ}$

BDCQ

Hydroxychloroquine

Desethylchloroquine

Bisdesethylchloroquine Monodesethylhydroxychloroquin

Fig. 1: Chemical structures of HCQ and three major metabolites

Antimalarial drugs modulate the immune system through their known ability to influence the $\mathrm{pH}$ in intracytoplasmic vesicles. As discussed in the previous section, after fast absorption, the deposits of HCQ and CQ extensively distributes in the tissues. The drug is concentrated intracellularly, particularly in acidic cytoplasmic vesicles. The deposition of HCQ in immune system cells is the reason of its antirheumatic effect [6].

The novel virus spread (Covid-19) from Wuhan province of China in the year 2019 is now a threat for economy and health infrastructure
[7]. The world's apex health organization, WHO declared this as pandemic because of rapid spread in almost every part of the world $[8,9]$. In the stage of writing this article, the available literature indicates more than 300 clinical trails (ongoing), and different drugs are in the phase of evaluation for potential effects against covid-19 [10].

One of the advantages of HCQ over its parent drug CQ is tolerance in higher doses form longer periods. The US FDA approved HCQ for its marketing in their country in 1994 [11]. The effect of HCQ and CQ on 
viral replication goes beyond the inhibition of cytokines. These drugs are weak bases known to influence acidic vesicles and inhibition of many enzymes. The enzyme glycosyl-transferases is inhibited by HCQ and decreasing the occurrence of viral replication of some of its families. This is believed to be one of the potential explanations of its antiretroviral mechanism of these drugs [12].

\section{HCQ and covid-19}

The fast outbreak of new coronavirus (SARS-CoV-2) has now become a serious concern for health for almost all countries of the world $[13,14]$. The mechanism of entry of this virus into the host cell is believed to be the result of interaction between ACE2 (Angiotensin-converting enzyme) and spiral protein of virus [15]. This is now established that elderly people and people with other comorbidities e. g. diabetes (TYPE 2) are in high risk with a high death rate [16]

In spite of best efforts by almost all health-related researchers, till the mid of June of this year, we have not found any therapeutic option for this virus and this is the reason of declared "public health emergency" in most of the countries, including Indian subcontinent. Researchers are investigating many drugs for treatment, including these low-cost antimalarials; HCQ and CQ [17].

The reputed government research organization of India, Indian Council of Medical Research (ICMR) recommended the dose of HCQ $400 \mathrm{mg}$ twice on day 1 and once/week after that) for chemoprophylaxis to health care workers handling patients of covid in both confirmed and suspected infections cases. Also recommended for household contacts (asymptomatic) for any confirmed cases [18]

The healthcare system of the whole world is facing an alarming situation because of spread of new coronavirus. Thus, there is an urgent requirement for therapeutic option for control of new coronavirus. HCQ is a derivative of Chloroquine (CQ), currently under investigation may be therapeutic option against COVID-19 infection. HCQ was found to have less acute poisoning than CQ and share a similar mechanism of action and structure [19].

The mechanism of action of HCQ against covid 19 virus is still under investigation. It is believed to change the $\mathrm{pH}$ of endosomes. Because of this the entry of virus, its transportation and postentry events are believed to be prevented [17]. The report suggests halting replication and modification of virus and also inhibition of glycosyltransferases [20]. In vivo, hydroxychloroquine is metabolized into chloroquine [21].

The HCQ and its parent drug CQ both have comparable pharmacological activity as antimalarial agents, but former if preferred due to less ocular toxicity. The available literature suggested the prolongation of QT interval by using CQ in combination with other antiretroviral drugs such as ritonavir or lopinavir, but this problem is less in HCQ and this is the reason of its selection for covid patients [22]

Thus, apart from the development of medication in this pandemic, there is a definite need of the literature presented here to help scientists or researchers involved in the investigation of development of a formulation of HCQ. This article is a comprehensive review of analytical methods published so far for the analysis of HCQ in a different mixture of components.

\section{MATERIALS AND METHODS}

Author searched various online libraries available online related to determination of Hydroxychloroquine. The databases searched are, pubmed, wiley, sciencedirect, taylor and francis, nature, BMJ and google scholar. The keywords used for search are 'determination of Hydroxychloroquine', 'estimation of Hydroxychloroquine', and 'Hydroxychloroquine in covid-19.

\section{Analytical methods}

\section{Spectrophotometry methods}

The quantitative analysis performed by spectrophotometry is due to the interaction of radiations of ultraviolet and some part of infrared region with sample and has an influence on variety of different fields of science and technology. There are many changes in a spectrophotometer in last few decades due to advancement in technology with inclusion of many new features for different type of samples and optical properties [23].

Five spectrophotometric methods [24-27] were found from various sources available in internet. Feraz et al. [24] used USP method [26] and performed quality by design in the determination of hydroxychloroquine in tablet formulations. The limit of quantitation and limit of quantitation found are 1.27 and $0.38 \mu \mathrm{g} / \mathrm{ml}$ respectively.

In another method $0.1 \mathrm{~N} \mathrm{HCl}$ was used as diluent and determination performed at same wavelength as in the previously described method. Pharmacopeial method found cited here is referred from United States Pharmacopoeia [25].

Two methods in single paper in which one involves simple spectrophotometry method and another first derivative method developed by Mehta and Patel. In this method water is used as diluent for the preparation of sample in contrast to other methods using acidic medium [27].

Table 1: Summary of UV spectrophotometry method

\begin{tabular}{|c|c|c|c|c|c|}
\hline $\begin{array}{l}\text { Calibration curve/Target } \\
\text { concentration }\end{array}$ & Solvent/Diluent & Wavelength & LOD and LOQ & Matrix & Reference \\
\hline $8-12 \mu \mathrm{g} / \mathrm{ml}$ & $0.01 \mathrm{M} \mathrm{HCl}$ & $342 \mathrm{~nm}$ & 0.38 and $1.27 \mu \mathrm{g} / \mathrm{ml}$ & Raw and formulation & {$[24]$} \\
\hline $1-20 \mu \mathrm{g} / \mathrm{ml}$ & $0.1 \mathrm{~N} \mathrm{HCl}$ & $343 \mathrm{~nm}$ & Not mentioned & Raw and formulation & [25] \\
\hline $10 \mu \mathrm{g} / \mathrm{ml}$ & Dil. $\mathrm{HCl}(1$ in 100$)$ & $343 \mathrm{~nm}$ & - & Raw material & [26] \\
\hline $2-12 \mu \mathrm{g} / \mathrm{ml}$ & Water & $\begin{array}{l}251-261 \mathrm{~nm} \\
347.80 \mathrm{~nm} \text { (First } \\
\text { derivative) }\end{array}$ & $\begin{array}{l}0.37,1.1212 \mu \mathrm{g} / \mathrm{ml} \\
0.3145,0.9530 \mu \mathrm{g} / \mathrm{ml}\end{array}$ & $\begin{array}{l}\text { Bulk drug and } \\
\text { formulation }\end{array}$ & [27] \\
\hline
\end{tabular}

\section{Chromatography methods}

There are three different characteristics of chromatography separations: (a) these are a physical method for separation of components; (b) involvement of two different phases, stationary phase and mobile phase; and (c) separation of components on the basis of distribution constants of individual components in stationary and mobile phase. There are several important factors responsible for the acceptable separation of sample [28].

The first paper related to the chromatography method was found to be published in 1985. HCQ and its metabolites are basic compounds and fluoresce at high $\mathrm{pH}$, facilitating sensitive detection using chromatographic methods. This may be the reason that most of the methods utilizing spectrometry detection are based on fluorescence technique. First published paper is assay for HCQ and three major metabolites (fig. 1), using fluorescence detection in blood and plasma of RA patients. In this method chloroquine was used as an internal standard. Nine different anti-inflammatory drugs indicated in rheumatoid arthritis administered together with HCQ were found not interfere with the method [29].

The next method is related to quantitation for HCQ and three major metabolites (fig. 1), in human plasma using a fluorescence detection method. Determinations were performed in two sets of samples (1) fresh and immediately prepared sample, (2) stored for $18 \mathrm{~d}$ in 
freezer prior for analysis. This method is useful for application in clinical samples, as claimed by researchers [30].

Determination of HCQ and its three metabolites in blood and urine samples is also available with the claimed to be without the interference of chloroquine or quinine in the sample. Analyses was performed in whole blood and urine samples from two healthy, male, adult volunteers during weekly antimalarial chemoprophylaxis. Fluorescence detector was used at $\lambda_{\mathrm{ex}}=320 \mathrm{~nm}$ and $\lambda_{\mathrm{em}}=380 \mathrm{~nm}$ [31].

Wainer and Iredale (1992) developed method for the determination of the enantiomers of hydroxychloroquine, and three major metabolites (fig. 1), in plasma, using a Chiral-AGP chiral stationary phase. Method validated for the pharmacokinetic of HCQ in rabbit and includes two steps (1) achiral chromatography and (2) enantioselective chromatography using two different mobile phases [32].

Another method is achiral-chiral HPLC system has been developed for the quantitative analysis of HCQ in urine. Determinations performed for HCQ and the same three metabolites discussed earlier. This study complies the analysis in single oral dose pharmacokinetic study (200 mg HCQ sulfate) [33].

Analysis and separation method of HCQ enantiomers and metabolites in two steps, developed by Wei et al. [34]. In this method authors found unsatisfactory separation using chiral column for HCQ enantiomers and thus developed method in two stages. In the first step achiral separation is performed and racemates were collected. The second step is the separation of enantiomers using chiral column for drugs and metabolites [34].

Another HPLC method for analysis of quinine, HCQ, CQ and DCQ is also available. The method is applied in whole blood, serum, and blood (dried) adsorbed in filter paper. The method is useful for analysis in a particularly small volume. Method described fluorescence detection and claimed to obtained within an hour of receipt of the sample [35].

Another HPLC method in serum samples for simultaneous determination of HCQ, CQ and corticosteroids from rheumatoid arthritis patients developed by Volin [36]. Patients received HCQ sulphate or CQ diphosphate and then determination performed in serum samples using diode array detection [36].

Method to quantify enantiomers is described and applied in determination of HCQ in rat liver microsomes. This is a single-step method for chiral separation using UV detection $(\lambda=343 \mathrm{~nm})$ [37].

The LC-MS/MS determination is performed by using hydroxychloroquine-d4 as the internal standard. A high throughput analysis is claimed, as run time is just three minutes and applied in human plasma [38].

The LC-MS/MS analysis is performed for the separation of three metabolites and parent drug (HCQ) in human plasma. Method may be applied for monitoring blood concentration of drug and metabolites, especially in the case of poisoning [39].

Plasma determination of HCQ was developed and validated by using the RP-HPLC-UV method using chloroquine as an internal standard [40].

Fluorescence detection clubbed with HPLC method is also available and applied used to monitor the blood level of HCQ in Systemic Lupus Erythematosus (SLE) patients [41].

An UPLC method using UV detection is developed, aimed for analysis of HCQ in serum samples. Method is applied for monitoring drug concentration in patients suffering from Whipple's disease and $Q$ fever [42].

A VAMS method (volumetric absorptive microsampling) based LCMS/MS method is also reported for therapeutic drug monitoring. The absorption of a fixed volume of blood $(10 \mu \mathrm{l})$ is possible by using VAMS method, with decreased variations in sampling especially problems related to dried blood spot are its additional advantages [43].

An HPLC-FL ion-pairing method for the determination of HCQ with its three metabolites i.e. DHCQ, DCQ, and BDCQ is also available. The method was applied for monitoring drug concentration in in patients suffering from Systemic Lupus Erythematosus (SLE). The method was also compared with the already available LC/MS/MS method and claimed to be applied for routine clinical monitoring [44].

The quantitation of HCQ and its three metabolites (DHCQ, DCQ, and BDCQ) in blood and tissues through LC-MS/MS is one of the recent publication. Method can also be utilized for pharmacokinetic monitoring of HCQ [45].

A recent published HPTLC with UV detection method is for the simultaneous determination of three different drugs in blood and urine samples of RA patients. The principles of Quality by Design were also used. Therapeutic monitoring and pharmacokinetic determination of drug are applications of this method [46].

\section{Electroanalytical methods}

The recent development of electrical methods for analytical determinations makes them more selective, sensitive, rapid and easy compared to the equipment available after its development and now applicable for most of the fields of pharmaceutical and chemical analysis. Electrochemical methods nowadays enables usage for trace analysis also for pharmaceuticals with a sufficient degree of precision, accuracy, selectivity, sensitivity and reproducibility [47].

A differential pulse voltammetry method using glassy carbon electrodes developed by Arguelho et al. [48]. This is the first electrochemical method found in the available literature. Best current for analysis of HCQ was obtained at $\mathrm{pH} 4$ and scan rate between 2 and $8 \mathrm{mV} / \mathrm{s}$. In the width higher than $100 \mathrm{mV}$ researchers observed loss of resolution. The detection limit reported is $11.29 \pm 2.6 \mathrm{mg} \mathrm{ml}^{-1}[48]$.

The first capillary electrophoresis method for simultaneous analysis of hydroxychloroquine (HCQ) with its three metabolites, in microsomal fraction of liver homogenates. The quantitation limit reported is $125 \mathrm{ng} / \mathrm{ml}$, and detection performed at $220 \mathrm{~nm}$. The researchers found that major metabolite of HCQ by microsomal enzymes is (-)-(R)-desethylhydroxychloroquine (DHCQ) [49]. Another capillary electrophoresis method for determination of $\mathrm{HCQ}$, its enantiomers and metabolites in the concentration range of $10-$ $1000 \mathrm{ng} / \mathrm{ml}$ for parent drug applied in human urine. The limit of detection and quantitation values reported were 10 and $21 \mathrm{ng} / \mathrm{ml}$ respectively [50].

In other electrochemical method determination was performed by using glassy carbon electrode prepared in laboratory by using cyclic voltametry, double potential step chronocoulometry and linear sweep voltammetry (LSV) techniques. The detection limit reported in this method is $4.65 \mathrm{nM}$. The prepared modified electrode was then utilized for determining of HQ in human body fluids [51].

Determination of HCQ in synthetic urine and in pharmaceutical tablets by the square-wave voltammetry method is also available. The reported detection limit is $0.06 \mu \mathrm{mol} \mathrm{L}^{-1}$. The electrode utilized was cathodically pretreated (CPT) boron-doped diamond (BDD) electrode [52].

Potentiometric determination of HCQ in pure form, tablets and human urine samples using standard addition method. Silver-silver chloride and modified paste electrodes were used for analysis. The limit of detection reported was up to $5.0 \times 10-6 \mathrm{~mol} \mathrm{~L}^{-1}$ [53]. Similar method by using coated graphite electrode (CGE) is also reported. The detection limit found is $1.8 \times 10^{-5} \mathrm{~mol} \mathrm{~L}^{-1}$ and response time $\leq$ $10 \mathrm{~s}$ [54]. 
Table 2: Summary of chromatography methods

\begin{tabular}{|c|c|c|c|c|c|c|c|c|}
\hline Method & Column & Mobile phase & pH & Flow rate & LOD & LOQ & Matrix & Reference \\
\hline HPLC-F & $\begin{array}{l}\text { Poly(styrene } \\
\text { divinylbenzen } \\
\text { e) packing }\end{array}$ & Methanol (80): Water(20) & 11 & $1 \mathrm{ml} / \mathrm{min}$ & - & - & $\begin{array}{l}\text { Blood and } \\
\text { plasma }\end{array}$ & [29] \\
\hline HPLC-UV & $\mathrm{CN}$ & $\begin{array}{l}0.06 \text { M Dibutylamine Phosphate } \\
\text { (40): } 0.05 \text { M Monobasic sodium } \\
\text { Phosphate (60) }\end{array}$ & 3.5 & $1.2 \mathrm{ml} / \mathrm{min}$ & - & - & Plasma & {$[30]$} \\
\hline HPLC-F & ODS & $\begin{array}{l}\text { Hexane: tert butyl ether: } 0.5 \% \mathrm{n}- \\
\text { butylamine in methanol }(1: 1: 1)\end{array}$ & - & $1 \mathrm{ml} / \mathrm{min}$ & $10 \mathrm{ppb}$ & - & $\begin{array}{l}\text { Blood and } \\
\text { urine }\end{array}$ & [31] \\
\hline HPLC-UV & $\mathrm{CN}$ & $\begin{array}{l}0.03 \mathrm{M} \text { sodium phosphate buffer, } \\
\text { pH } 7.0 \text {-ethanol-acetonitrile } \\
(79: 20: 1)\end{array}$ & - & $0.9 \mathrm{ml} / \mathrm{min}$ & $\begin{array}{l}10 \\
\mathrm{ng} / \mathrm{ml}\end{array}$ & - & Plasma & [32] \\
\hline HPLC-UV & $\mathrm{CN}$ & $\begin{array}{l}\mathrm{Na}_{3} \mathrm{PO}_{4} \text { Buffer }(0.03 \mathrm{~mol} / \mathrm{l}) \text {; } \\
\text { ethanol; and acetonitrile (79:20: I }\end{array}$ & - & $0.7 \mathrm{ml} / \mathrm{min}$ & - & - & $\begin{array}{l}\text { Plasma and in } \\
\text { urine }\end{array}$ & [33] \\
\hline HPLC-UV & ODS & $\begin{array}{l}\text { Phosphate buffer-methanol: } \\
\text { ethanol: Triethanolamine } \\
(78: 22: 1: 0.08, \mathrm{v} / \mathrm{v})\end{array}$ & $\begin{array}{l}\text { Buffer } \\
\text { pH } \\
3.5\end{array}$ & $\begin{array}{l}0.75-0.8 \\
\mathrm{ml} / \mathrm{min}\end{array}$ & - & - & Plasma & [34] \\
\hline HPLC-F & $\mathrm{CN}$ & $\begin{array}{l}0.015 \mathrm{M} \mathrm{K}_{2} \mathrm{HPO}_{4} \text { buffer: Methanol: } \\
\text { ACN }(20: 30: 50)\end{array}$ & $\begin{array}{l}\text { Buffer } \\
\text { pH } 6\end{array}$ & $2 \mathrm{ml} / \mathrm{min}$ & $<1 \mathrm{ng}$ & - & Blood & [35] \\
\hline HPLC-F & Silica & $\begin{array}{l}\text { Methanol: water }(98.5: 1.5)+ \\
4.705 \mathrm{~g} \mathrm{NH}_{4} \mathrm{ClO}_{4}\end{array}$ & 8.0 & $1.5 \mathrm{ml} / \mathrm{min}$ & - & $\begin{array}{l}0.005-0.01 \\
\mathrm{mg} / \mathrm{l}\end{array}$ & $\begin{array}{l}\text { Serum, whole } \\
\text { blood or filter } \\
\text { paper- } \\
\text { adsorbed dry } \\
\text { blood }\end{array}$ & {$[36]$} \\
\hline $\begin{array}{l}\text { HPLC- } \\
\text { PDA }\end{array}$ & ODS & $\begin{array}{l}58 \text { mmol } \\
\text { monobasic } \mathrm{NaH}_{2} \mathrm{PO}_{4} \text { buffer ( } 7 \\
\mathrm{~g} / \mathrm{l}),+6 \mathrm{mmol} \text { heptanesulfonic } \\
\text { acid (sodium salt) }(1.3 \mathrm{~g} / \mathrm{l})\end{array}$ & 3.1 & $1.0 \mathrm{ml} / \mathrm{min}$ & $\begin{array}{l}2 \\
\mathrm{ng} / \mathrm{ml}\end{array}$ & - & Serum & [37] \\
\hline HPLC-UV & $\mathrm{C} 8$ & $\begin{array}{l}\text { Hexane: Isopropanol }(92: 8)+0.1 \\
\text { \% Diethyl amine }\end{array}$ & - & $1.0 \mathrm{ml} / \mathrm{min}$ & - & $\begin{array}{l}125 \\
\text { ngmL }^{-1}\end{array}$ & $\begin{array}{l}\text { Rat liver } \\
\text { microsomes }\end{array}$ & [38] \\
\hline $\begin{array}{l}\text { LC- } \\
\text { MS/MS }\end{array}$ & $\mathrm{C} 8$ & $\begin{array}{l}\text { Formic acid(0.1\%): } \operatorname{ACN}(94: 6 \text {, } \\
\text { v/v) }\end{array}$ & - & $0.5 \mathrm{ml} / \mathrm{min}$ & $\begin{array}{l}2 \\
\mathrm{ng} / \mathrm{ml}\end{array}$ & - & Blood & [39] \\
\hline $\begin{array}{l}\text { LC- } \\
\text { MS/MS }\end{array}$ & ODS & $\begin{array}{l}\text { Water and methanol } \\
\text { (Gradient) }+0.1 \% \text { formic acid }\end{array}$ & - & $0.5 \mathrm{ml} / \mathrm{min}$ & - & $25 \mathrm{ng} / \mathrm{ml}$ & Blood & {$[40]$} \\
\hline HPLC-UV & ODS & $\begin{array}{l}\text { Water: Solvent (ACN: methanol: } \\
50: 50 \text { ) in ratio } 75: 25\end{array}$ & $\begin{array}{l}3.0 \\
\text { (Solve } \\
\text { nt) }\end{array}$ & $2.0 \mathrm{ml} / \mathrm{min}$ & $\begin{array}{l}0.24 \\
\mu \mathrm{g} / \mathrm{ml}\end{array}$ & $0.84 \mu \mathrm{g} / \mathrm{ml}$ & Plasma & [41] \\
\hline HPLC-F & ODS & $\begin{array}{l}\text { Glycine buffer } / \mathrm{NaCl}(\mathrm{pH} 9.7,100 \\
\text { mmol) and methanol (46:54; v/v) }\end{array}$ & - & $1.2 \mathrm{ml} / \mathrm{min}$ & $\begin{array}{l}25 \\
\mathrm{ng} / \mathrm{ml}\end{array}$ & - & Blood & [42] \\
\hline $\begin{array}{l}\text { UHPLC- } \\
\text { UV }\end{array}$ & $\mathrm{C}_{18}$ & $\begin{array}{l}1 \% \text { triethylamine and } 1 \mathrm{mmol} \\
\text { oxalic acid }\end{array}$ & 2.4 & $0.5 \mathrm{ml} / \mathrm{min}$ & - & $0.25 \mu \mathrm{g} / \mathrm{ml}$ & Serum & [43] \\
\hline $\begin{array}{l}\mathrm{LC}- \\
\mathrm{MS} / \mathrm{MS}\end{array}$ & $\mathrm{C} 8$ & $\begin{array}{l}0.1 \% \mathrm{HCOOH} \text { and } 0.01 \% \\
\text { triethylamine in water (or } \\
\text { acetonitrile) }\end{array}$ & & $0.5 \mathrm{ml} / \mathrm{min}$ & $\begin{array}{l}5 \\
\mathrm{ng} / \mathrm{ml}\end{array}$ & $10 \mathrm{ng} / \mathrm{ml}$ & Blood & [44] \\
\hline HPLC-FL & ODS & Water: methanol: ACN $(47: 10: 43$ & 9.4 & $1.0 \mathrm{ml} / \mathrm{min}$ & - & $20 \mathrm{ng} / \mathrm{ml}$ & Blood & [45] \\
\hline $\begin{array}{l}\text { LC-ESI- } \\
\text { MS/MS }\end{array}$ & $\mathrm{C}_{18}$ & $\begin{array}{l}\text { Gradient: Part A: } 0.2 \% \text { formic } \\
\text { acid in water, Part B: } 0.1 \% \text { formic } \\
\text { acid in methanol }\end{array}$ & - & $2.0 \mathrm{~L} / \mathrm{min}$ & $\begin{array}{l}1 \\
\mathrm{ng} / \mathrm{ml}\end{array}$ & - & $\begin{array}{l}\text { Blood and } \\
\text { tissues. }\end{array}$ & [46] \\
\hline HPTLC & - & $\begin{array}{l}\text { Ethyl acetate: methanol: } 25 \% \\
\text { ammonia, (8: } 2: 3)\end{array}$ & - & - & $\begin{array}{l}260.64 \\
\mathrm{ng} / \mathrm{ml}\end{array}$ & $\begin{array}{l}1810.01 \\
\mathrm{ng} / \mathrm{ml}\end{array}$ & $\begin{array}{l}\text { Serum and } \\
\text { urine } \\
\text { samples }\end{array}$ & [47] \\
\hline
\end{tabular}

\section{DISCUSSION}

The CQ and its hydroxyl derivative HCQ are weak bases with five decades usage as antimalarial agents [55]. HCQ is one of the drugs generated significant interest for the treatment of COVID-19 infection. There are research published providing some idea about the activity of HCQ against this novel coronavirus [56].

HCQ a member of the group of 4-aminoquinolines [57] and is a slow-acting antirheumatic drug [58]. It is administered as a racemic mixture [rac-HCQ] of two isomers, $R(-)-\mathrm{HCQ}$ and $S(+)-\mathrm{HCQ}$. The hepatic metabolism generates three metabolites, DHCQ, BDCQ and DCQ. These three molecules are also chiral molecules [59].

There are five spectrophotometry methods found in the available literature. These all methods are for routine quality control of HCQ in bulk or formulations. Spectrophotometry methods are cheaper than chromatography. There are limited methods available for the determination of HCQ with nearly the same procedures and dilutions. The summary is provided under table 1 .
The HPLC methods are versatile and can be used as both analytical and preparative technique. Organic molecules are detected after exit from column using absorption pattern in UV/Visible radiation. As described in spectrophotometry method, HCQ showing maximum absorption at $342 \mathrm{~nm}$ in UV region, many chromatography coupled with spectrophotometry detection method were developed [60]. The testing of enantiomers are quite often with HPLC in last few decade. The chiral stationary phase enables separation based on interaction between stationary phase (chiral) and isomers [61]. LC-MS methods nowadays emerged as powerful tool in analytical chemistry for complex samples for both quantitative and qualitative analysis. These methods possessing high separation power, high sensitivity and facilitates research with detailed information of analyte's identity [62]. Different types of chromatography methods are available in the literature for the determination of HCQ in different matrices. The summary of chromatography methods are described under table 2 .

The research-based on photochemical degradation of HCQ, followed by HPLC is also available. Degradation performed by an immersion 
lamp with emission wavelengths of 240-600 nm, $120 \mathrm{~W}$. Degradation products were isolated first by using preparative TLC and isolated fractions were then identified using MS detection method [63].

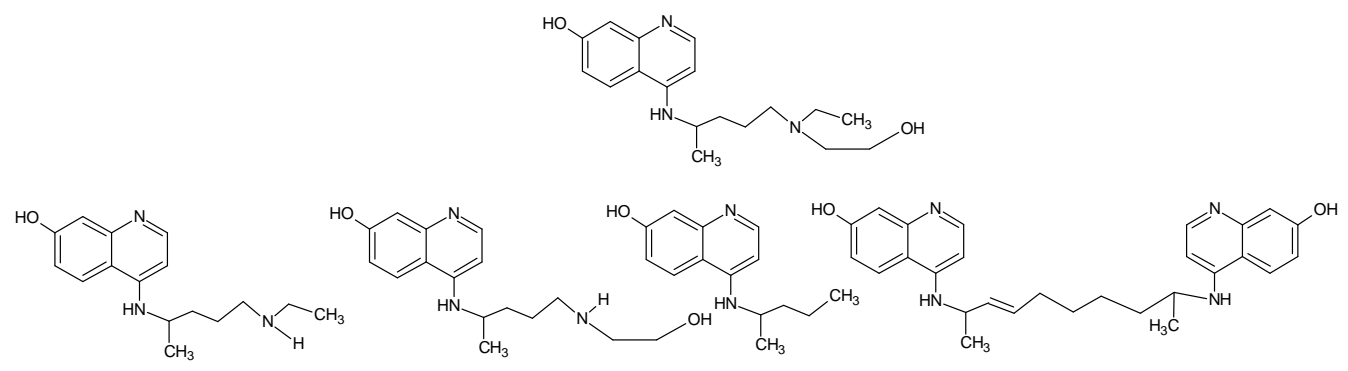

Fig. 2: Photodegradation of HCQ in water and isopropyl alcohol [63]

There is another paper described forced degradation studies of HCQ. The stress conditions applied for degradation of drug through hydrolysis, dry heat and photolysis. The researchers found six different degradation products when photolytic degradation was attempted under alkaline conditions. The products were characterized through LC-MS-TOF, LC-ESI-MS and LC-PDA studies [64].<smiles>CCNCCCC(C)Nc1ccnc2cc(O)ccc12</smiles>

Fig. 3: Five degradation products of HCQ, sixth degradation not characterized [64]

In another study the samples used were HCQ solutions in water from a different source; spring, sea, river and ultrapure water and photolytic decomposition of HCQ investigated using simulated solar radiation (300-800 $\mathrm{nm})$. It was found that humic acids, nitrate and iron (III) enhanced the photodegradation of HCQ due to the formation of hydroxyl radicals and their attack on the molecule of HCQ. Contrary to this, chloride, bromide and sulfate inhibited the photodegradation of HCQ [65].

\section{Future aspects}

There are a limited number of spectrophotometry methods available in the literature. There are many methods available in which chromophore is added in molecule by any chemical reaction to increase the absorbance in UV region. This is one of the ways to increase the sensitivity of method. While going through this particular class of analytical method for determination of HCQ, and to the best of knowledge of author, no such method has been developed and validated. Stability indicating method using spectrophotometry analysis is also not found. However, this is also well evident that the separation of analytes using simple UV-Vis is difficult as compared to chromatographic methods. There are different types of chromatographic methods available in the literature including HPTLC method. The HPTLC method for the determination of HCQ is still needs to be explored. The stabilityindicating HPTLC method is also not available.

\section{CONCLUSION}

The FDA of United States approved HCQ in 1955 and licensed for a treatment option for SLE and inflammatory arthritis before the outbreak of new coronavirus. This drug in the current scenario HCQ is receiving the attention of our scientists because of its action in immune system and antiretroviral effect. India has enormous potential and capacity of manufacturing HCQ tablets in large scale. There is a surge in demand of HCQ after covid pandemic from almost every part of world due to its potential activity against this virus. However, more studies are required to establish its activity in improving conditions of covid patients. The activity of HCQ against covid 19 virus is already discussed in the introductory section. In the current scenario, covid is biggest enemy of humanity. The socioeconomical implications due to lockdown is believed to be huge. Thus, there is a sudden need for any drug to save the life of covid patients and scientists in almost all parts of the world are engaged in the development of suitable drug. The review is presented with an aim to help scientists or researchers involved in the development of the formulation of HCQ. Different spectrophotometry, chromatography and electroanalytical methods are presented here in a systematic way and easy understandable language.

\section{FUNDING}

Nil

\section{AUTHOR CONTRIBUTION}

The whole work carried by me.

\section{CONFLICT OF INTERESTS}

None

\section{REFERENCES}

1. Cannella AC, O'Dell JR. Traditional DMARDs. Kelley and Firestein's Textbook of Rheumatology; 2017. p. 958-82. DOI:10.1016/b978-0-323-31696-5.00061-9. 
2. British Pharmacopoeia. Available from: https://www. pharmacopoeia.com/ban-2012/ban-2017.pdf. [Last assessed on 18 Apr 2020].

3. Jordan P, Brookes JG, Nikolic G, Le Couteur DG. Hydroxychloroquine overdose: toxicokinetics and management. J Toxicol Clin Toxicol 1999;37:861-4.

4. National Centre for Biotechnology Information. PubChem Database. Hydroxychloroquine, $\mathrm{CID}=3652$. Available from: https://pubchem.ncbi.nlm.nih.gov/compound/Hydroxychloro quine [Last accessed on $18 \mathrm{Apr} 2020]$.

5. Collins KP, Jackson KM, Gustafson DL. Hydroxychloroquine: a physiologically-based pharmacokinetic model in the context of cancer-related autophagy modulation. J Pharmacol Exp Ther 2018;365:447-59.

6. Fox RI. Mechanism of action of hydroxychloroquine as an antirheumatic drug. Semin Arthritis Rheum 1993;23(2 Suppl 1):82-91.

7. Liu J, Cao $\mathrm{R}, \mathrm{Xu} \mathrm{M}$, Wang $\mathrm{X}$, Zhang $\mathrm{H}, \mathrm{Hu} \mathrm{H}$, et al. Hydroxychloroquine, a less toxic derivative of chloroquine, is effective in inhibiting SARS-CoV-2 infection in vitro. Cell Discovery 2020;6:16.

8. WHO Director-General's opening remarks at the media briefing on Covid-19; 2020. Available from: https://www.who.int/ $\mathrm{dg} /$ speeches/detail/who-directorgeneral-s-opening-remarksatthe-media-briefing-on-covid-19 [last accessed on 11 Mar 2020].

9. Pedersen SF, Ho YC. SARS-CoV-2: a storm is raging. J Clin Invest 2020;13pii:137647. DOI:10.1172/JCI137647.

10. Yavuz S, Unal S. Antiviral treatment of Covid-19. Turk J Med Sci 2020;50:611-9.

11. LiverTox: Clinical and research information on drug-induced liver injury. Bethesda (MD): National Institute of Diabetes and Digestive and Kidney Diseases; 2012.

12. Sinha N, Balayla G. Hydroxychloroquine and covid-19. Postgrad Med J 2020. DOI:10.1136/postgradmedj-2020-137785.

13. Saqrane S, El Mhammedi MA. Review on the global epidemiological situation and the efficacy of chloroquine and hydroxychloroquine for the treatment of Covid-19. New Microbes New Infect 2020;35:100680.

14. Taghizadeh Hesary F, Akbari $\mathrm{H}$. The powerful immune system against powerful Covid-19: A hypothesis. Med Hypotheses 2020;140:109762.

15. Krejner Bienias A, Grzela K, Grzela T. Do novel drugs for diabetes will help in COVID-19? Another brick in the wall? 2020. DOI:10.1111/1753-0407.13050.

16. Inamo J. How should we overcome the threat by the pandemic of 2019-nCoV? Epidemic simulation using the SIRS model. Clin Rheumatol 2020;9:1-3.

17. Singh AK, Singh A, Shaikh A, Singh R, Misra A. Chloroquine and hydroxychloroquine in the treatment of Covid-19 with or without diabetes: a systematic search and a narrative review with a special reference to India and other developing countries. Diabetes Metab Syndr 2020;14:241-6.

18. Rathi S, Ish P, Kalantri A, Kalantri S. Hydroxychloroquine prophylaxis for COVID-19 contacts in India. Lancet Infect Dis 2020. DOI:10.1016/S1473-309930313-3.

19. Choudhary R, Sharma AK, Choudhary R. Potential use of hydroxychloroquine, ivermectin and azithromycin drugs in fighting Covid-19: trends, scope and relevance. New Microbes New Infect 2020:100684. DOI:10.1016/j.nmni.2020.100684.

20. Sinha N, Balayla G. Hydroxychloroquine and covid-19. Postgraduate Med J 2020. DOI:10.1136/postgradmedj-2020137785.

21. McKee DL, Sternberg A, Stange U, Laufer S, Naujokat C. Candidate drugs against SARS-CoV-2 and Covid-19. Pharmacol Res 2020;157:104859.

22. Patil VM, Singhal S, Masand N. A systematic review on use of aminoquinolines for the therapeutic management of Covid-19: Efficacy, safety and clinical trials. Life Sci 2020. DOI: https://doi.org/10.1016/j.lfs.2020.117775.

23. Germer TA, Zwinkels JC, Tsai BK. Spectrophotometry accurate measurement of optical properties of materials. In: Experimental methods in the physical sciences. Elsevier Inc 2014;46:2-533.
24. Ferraz LRM, Santos FLA, Ferreira PA, Maia-Junior RTL, Rosa TA, Costa SPM, et al. Quality by design in the development and validation of analytical method by ultraviolet-visible spectrophotometry for quantification of hydroxychloroquine sulfate. Int J Pharm Sci Res 2014;5:4666-76.

25. Singh A, Kishora R, Sharma PK, Gupta R, Mondal N, Kumar S, et al. Development and validation of UV-spectrophotometric method for the estimation of hydroxychloroquine sulphate. Indian J Chem Technol 2016;23:237-9.

26. USP29-NF24 Page 1086.

27. Mehta SS, Patel MB. Development and validation of UV spectrophotometric method for the determination of hydroxychloroquine in bulk and tablet formulation. Pharma Sci Monitor 2012;3: Suppl 2:2959-67.

28. Poole CF. The essence of chromatography. First Edition. Elsevier Science; 2003. p. 2, 4.

29. Tett SE, Cutler DJ, Brown KF. High-performance liquid chromatographic assay for hydroxychloroquine and metabolites in blood and plasma, using a stationary phase of poly(styrene divinylbenzene) and a mobile phase at $\mathrm{pH} 11$, with fluorimetric detection. J Chromatogr 1985;344:241-8.

30. Brown RR, Stroshane RM, Benziger DP. High-performance liquid chromatographic assay for hydroxychloroquine and three of its major metabolites, desethylhydroxychloroquine, desethylchloroquine and bidesethylchloroquine, in human plasma. J Chromatogr 1986;377:454-9.

31. Williams SB, Patchen LC, Churchill FC. Analysis of blood and urine samples for hydroxychloroquine and three major metabolites by high-performance liquid chromatography with fluorescence detection. J Chromatogr 1988;433:197-206. DOI:10.1016/s0378-434780598-8.

32. Iredale J, Wainer IW. Determination of hydroxychloroquine and its major metabolites in plasma using sequential achiral-chiral high-performance liquid chromatography. J Chromatogr 1992;573:253-8.

33. Fieger H, Iredale J, Wainer IW. Enantioselective determination of hydroxychloroquine and its major metabolites in urine and the observation of a reversal in the $(+) /(-)$-hydroxychloroquine ratio. Chirality 1993;5:65-70.

34. Yimin Wei, Gloria A Nygard, Shoukry KW Khalil. A HPLC method for the separation and quantification of the enantiomers of hydroxychloroquine and its three major metabolites. J Liq Chromatr 1994;17:3479-90.

35. Croes K, McCarthy PT, Flanagan RJ. Simple and rapid HPLC of quinine, hydroxychloroquine, chloroquine, and desethylchloroquine in serum, whole blood, and filter paperadsorbed dry blood. J Anal Toxicol 1994;18:255-60.

36. Volin P. Simple and specific reversed-phase liquid chromatographic method with diode-array detection for simultaneous determination of serum hydroxychloroquine, chloroquine and some corticosteroids. J Chromatogr B Biomed Appl 1995;666:347-53.

37. Cardoso CD, Bonato PS. Enantioselective analysis of the metabolites of hydroxychloroquine and application to an in vitro metabolic study. J Pharm Biomed Anal 2005;37:703-8.

38. Wang LZ, Ong RY, Chin TM, Thuya WL, Wan SC, Wong AL, et al. Method development and validation for rapid quantification of hydroxychloroquine in human blood using liquid chromatography-tandem mass spectrometry. J Pharm Biomed Anal 2012;61:86-92.

39. Soichot M, Megarbane B, Houze P, Chevillard L, Fonsart J, Baud FJ, et al. Development, validation and clinical application of a LC-MS/MS method for the simultaneous quantification of hydroxychloroquine and its active metabolites in human whole blood. J Pharm Biomed Anal 2014;100:131-7.

40. Singh A, Roopkishora, Singh CL, Gupta R, Kumar S, Kumar M. Development and validation of reversed-phase high performance liquid chromatographic method for hydroxychloroquine sulphate. Indian J Pharm Sci 2015;77:58691.

41. Qu Y, Noe G, Breaud AR, Vidal M, Clarke WA, Zahr N, et al. Future sci OA. 2015;1:FSO26.

42. Armstrong N, Richez M, Raoult D, Chabriere E. Simultaneous UHPLC-UV analysis of hydroxychloroquine, minocycline and 
doxycycline from serum samples for the therapeutic drug monitoring of Q fever and Whipple's diseases. J Chromatogr B: Anal Technol Biomed Life Sci 2017;1060:166-72.

43. Qu Y, Brady K, Apilado R, O'Malley T, Reddy S, Chitkara P, et al. Capillary blood collected on volumetric absorptive microsampling (VAMS) device for monitoring hydroxychloroquine in rheumatoid arthritis patients. J Pharm Biomed Anal 2017;140:334-41.

44. Charlier B, Pingeon M, Dal Piaz F, Conti V, Valentini G. Development of a novel ion-pairing HPLC-FL method for the separation and quantification of hydroxychloroquine and its metabolites in whole blood. Biomed Chromatogr 2018;32:e4258.

45. Chhonker YS, Sleightholm RL, Li J, Oupický D, Murry DJ. Simultaneous quantitation of hydroxychloroquine and its metabolites in mouse blood and tissues using LC-ESI-MS/MS: An application for pharmacokinetic studies. J Chromatogr B: Anal Technol Biomed Life Sci 2018;1072:320-7.

46. El-Koussi WM, Atia NN, Saleh GA, Hammam N. Innovative HPTLC method for simultaneous determination of ternary mixture of certain DMARDs in real samples of rheumatoid arthritis patients: an application of quality by design approach. J Chromatogr B: Anal Technol Biomed Life Sci 2019;1124:13545.

47. Shrivastava A. Analytical methods for venlaflaxine hydrochloride and metabolites determinations in different matrices. Syst Rev Pharm 2012;3:42-50.

48. Arguelho ML, Andrade JF, Stradiotto NR. Electrochemical study of hydroxychloroquine and its determination in plaquenil by differential pulse voltammetry. J Pharm Biomed Anal 2003;32:269-75.

49. Dickow Cardoso C, Polisel Jabor VA, Sueli Bonato P. Capillary electrophoretic chiral separation of hydroxychloroquine and its metabolites in the microsomal fraction of liver homogenates. Electrophoresis 2006;27:1248-54.

50. de Oliveira AR, Cardoso CD, Bonato PS. Stereoselective determination of hydroxychloroquine and its metabolites in human urine by liquid-phase microextraction and CE. Electrophoresis 2007;28:1081-91.

51. Khoobi A, Ghoreishi SM, Behpour M, Shaterian M, Salavati Niasari M. Design and evaluation of a highly sensitive nanostructure-based surface modification of glassy carbon electrode for electrochemical studies of hydroxychloroquine in the presence of acetaminophen. Colloids Surf B 2014;123:64856.

52. Deroco PB, Vicentini FC, Oliveira GG, Rocha Filho RC, Fatibello Filho 0 . Square-wave voltammetric determination of hydroxychloroquine in pharmaceutical and synthetic urine samples using a cathodically pretreated boron-doped diamond electrode. J Electroanal Chem 2014;719:19-23.

53. Khalil MM, Issab YM, El Sayed GA. Modified carbon paste and polymeric membrane electrodes for the determination of hydroxychloroquine sulfate in pharmaceutical preparations and human urine. RSC Adv 2015;5:83657-67.

54. Khalil MM, Issab YM, El Sayed GA. Development of a new coated graphite electrode for hydroxychloroquine sulfate determination in pharmaceutical preparations and human urine. Inter J Adv Res 2015;3:592-603.

55. Rolain JM, Colson P, Raoult D. Recycling of chloroquine and its hydroxyl analogue to face bacterial, fungal and viral infections in the 21st century. Int J Antimicrob Agents 2007;30:297-308.

56. Dousa KM, Malavade SS, Furin J, Gripshover B, Hatszegi M, Hojat L, et al. SARS-CoV-2 infection in a patient on chronic hydroxychloroquine therapy: implications for prophylaxis. ID Cases 2020:e00778. DOI:10.1016/j. idcr.2020.e00778.

57. Dabic D, Babic S, Skoric I. The role of photodegradation in the environmental fate of hydroxychloroquine. Chemosphere 2019;230:268-77.

58. Wei Y, Nygard GA, Ellertson SL, Khalil SK. Stereoselective disposition of hydroxychloroquine and its metabolite in rats. Chirality 1995;7:598-604.

59. Ducharme J, Fieger H, Ducharme MP, Khalil SK, Wainer IW. Enantioselective disposition of hydroxychloroquine after a single oral dose of the racemate to healthy subjects. Br J Clin Pharmacol 1995;40:127-33.

60. Crowley TE.High-performance liquid chromatography. Purification and Characterization of Secondary Metabolites; 2020. p. 49-58.

61. Sadiq NW, Beauchemin D. Liquid chromatography. Sample Introduction Systems in ICPMS and ICPOES; 2020. p. 213-54.

62. de Koster CG, Schoenmakers PJ. History of liquid chromatography-mass spectrometry couplings. Hyphenations of Capillary Chromatography with Mass Spectrometry; 2020. p. 279-95.

63. Tonnesen H, Grislingaas AL, Woo SO, Karlsen J. Photochemical stability of antimalarials. I. Hydroxychloroquine. Inter J Pharm 1988;43:215-9.

64. Saini B, Bansal G. Characterization of four new photodegradation products of hydroxychloroquine through LCPDA, ESI-MSn and LC-MS-TOF studies. J Pharm Biomed Anal 2013;84:224-31.

65. Dabic D, Babic S, Skoric I. The role of photodegradation in the environmental fate of hydroxychloroquine. Chemosphere 2019;230:268-77. 